\title{
Integrated learning based on competence in vocational high school
}

\author{
Pangarso Ari Wibowo', Tri Kuat' ${ }^{2}$, Muhammad Sayuti² \\ 1SMK N 1 Sayegan, Jl. Kebonagung KM 8.5, Margomulyo, Sleman, DIY 55561 Indonesia \\ 2Universitas Ahmad Dahlan, Jl. Pramuka 42, Sidikan, Yogyakarta, Indonesia \\ *Corresponding author, e-mail: pangarsoariw@gmail.com
}

\begin{abstract}
Education in Vocational High Schools (VHS) aims to equip learners with the attitude, knowledge, and skills to be ready for work, absorbed in the world of work, or entrepreneurship. To fulfill the objective, the competence that must be possessed by the students must be in accordance with the needs in the world of work and in the business world. To fulfill the competence, the learning in VHS must be competency-based. In line with the competency and competency-based learning needs, it also needs an integrated learning between adaptive subjects and productive subjects. Integrated learning is modeled by; (1) conducting curriculum study on basic competence of adaptive subjects, (2) inserting productive basic competency subjects on adaptive subjects. After the integrated learning model is prepared then the learning model applied to the class is a competency-based learning model.
\end{abstract}

Keywords: Adaptive, Competency-based learning, Integrated learning, Productive.

\begin{abstract}
Abstrak
Pendidikan di Sekolah Menengah Kejuruan (SMK) bertujuan untuk membekali peserta didik dengan sikap, pengetahuan, dan keterampilan untuk siap bekerja, terserap dalam dunia kerja, atau berwirausaha. Untuk memenuhi tujuan tersebut, kompetensi yang harus dimiliki oleh siswa harus sesuai dengan kebutuhan di dunia kerja dan di dunia bisnis. Untuk memenuhi kompetensi, pembelajaran di VHS harus berbasis kompetensi. Sejalan dengan kompetensi dan kebutuhan pembelajaran berbasis kompetensi, dibutuhkan pula pembelajaran yang terintegrasi antara mata pelajaran adaptif dan mata pelajaran produktif. Pembelajaran terpadu dimodelkan oleh; (1) melakukan studi kurikulum pada kompetensi dasar mata pelajaran adaptif, (2) memasukkan mata pelajaran kompetensi dasar produktif pada mata pelajaran adaptif. Setelah model pembelajaran terintegrasi disiapkan maka model pembelajaran yang diterapkan ke kelas adalah model pembelajaran berbasis kompetensi.
\end{abstract}

Kata Kunci: Adaptif, Pembelajaran berbasis kompetensi, Pembelajaran terintegrasi, Produktif.

\section{INTRODUCTION}

Competence is the ability, knowing, authorized, and powerful to decide or decide upon something (MOEC, 2016). Another definition according to the MOEC of Indonesia is the characteristics possessed by the individual and used appropriately in a consistent way to achieve the desired performance. Djojonegoro (1996) gives the understanding that competence is a basic characteristic possessed by an individual who is causally related to the standard of assessment that is referenced to superior performance or to a job.

Thus, the competencies that must be possessed by students to be proficient, consistent in achieving the desired performance, and superior in a job must include 3 domains, namely: knowledge, attitude, and skills that are always well trained during the education process so that students are said to be competent in the field of study or the work he or she is engaged in. Burke (1989) reveals that if we are clear about what we mean by competence, we can derive associated standards which describe what competence means in specific occupations and work roles. 
The phrase can be used as a benchmark that education in vocational school will bring its graduates to master a specific occupation, a field of work in which demand the mastery of competence, both from the general aspect as well as expertise. Therefore, the competency in SMK needs to be maximized.

The 2013 curriculum was first implemented in 2013 with implementation begun to schools that are considered ready. Prepared readiness from teachers, curriculum and learning tools, and the readiness of facilities and infrastructure. However, in its application, found in the 2013 curriculum some subjects on the adaptation group of basic competencies conveyed to learners is not a basic competency that reinforces basic competencies in subjects in productive groups.

One of the demands of 2013 curriculum is on the application of contextual learning model. Students' understanding towards any topic depends on the representation that te teacher brings into the classroom (Setyawan, et al., 2017). Thus, the recommended learning model is the problem-based learning, project-based learning, and discovery learning model. Learning models basically lead to training and competence development of learners or often known as competency-based learning model. Burke (1989) reveals that an important characteristic of the competence based standards is that they are very explicit. Certification is in effect a form of guarantee that the individual has adequately demonstrated that he or she has fully met the specification contained within the unit - unless specified, there is no scope for sampling.

Learning or training based on is a process to measure the competence of a learner through a real, standardized, measurable, and individual performance. Learning or training requires a long and continuous process ranging from simple materials to complex material in one or more periods and delivered in a classical or individual manner. Rothwell, Hohne, \& King (2012) wrote that the International Standards for Training, Performance and Instruction (IBSTPI) Board have developed a set of standards that use the direct definition of the term competency as " without him, a person is not a qualified practitioner". The above quotation indicates that to be able to implement a learning model or training based on competence, a teacher or trainer must meet some qualifications to be able to deliver learners to achieve competence or show their quality to a field of work.

CBT applied in VHS often encounters obstacles with not yet synchronized curriculum, that is on the basic competence delivered on adaptive subject which not yet according to basic competence on productive subject. In order to be synchronized then some of the basic competencies of productive subjects need to be inserted or added to be delivered on adaptive learning. This effort is then called integrated learning on adaptive subjects and productive subjects.

Integrated learning is differentiated based on the pattern of material or theme integration. Based on the theme, there are ten integrated learning models, namely: (1) the fragmented model, (2) the connected model, (3) the nested model, (4) the sequenced model, (5) the shared model, (6) the webbed model, (7) the threaded model, (8) the integrated model, (9) the immersed model, (10) the networked model (Fogarty, 1991). The ten models there are three models that can be developed and implemented in formal education. All three models are connected, webbed, and integrated models.

\section{RESEARCH METHOD}

This type of research in the form of research and development of Borg \& Gall (1983) with the flow diagram as in Figure 1. 


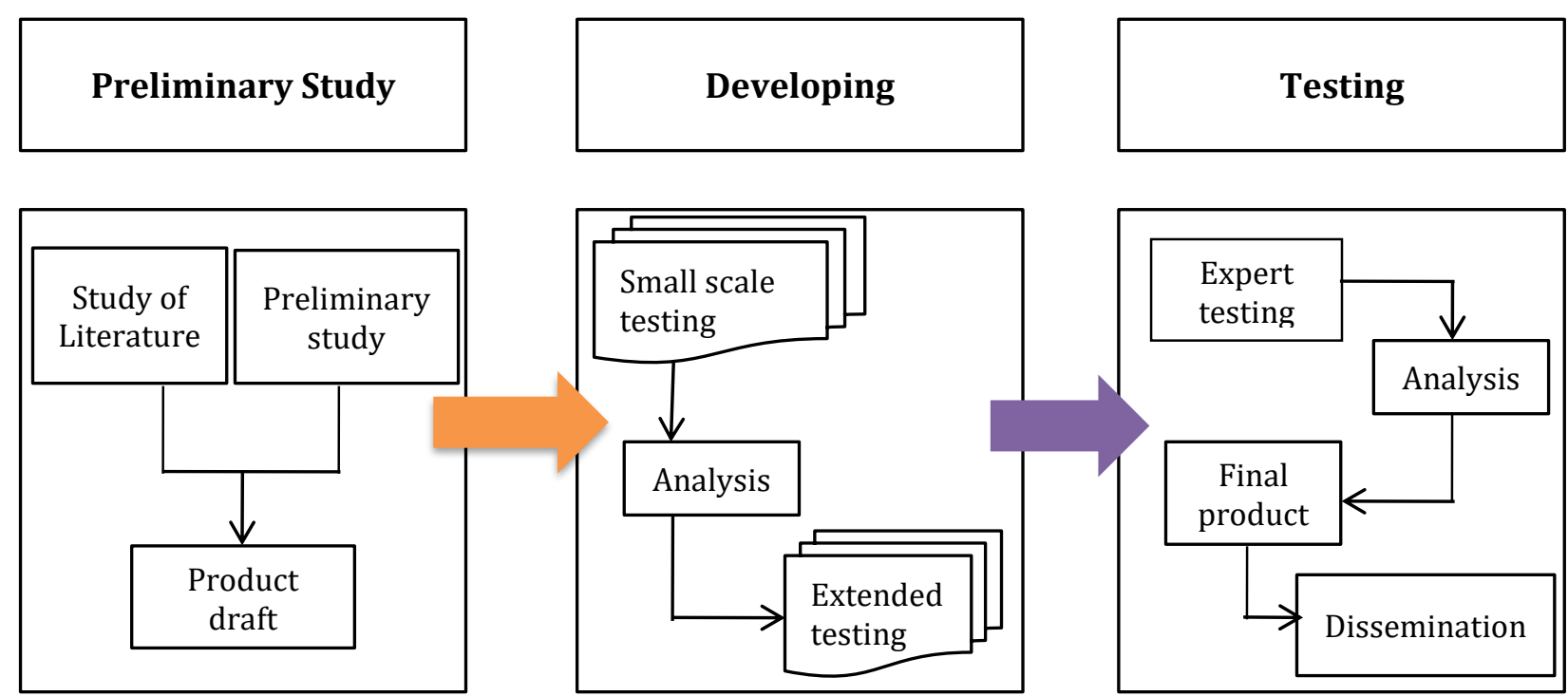

Figure 1. Diagram of the research flow

Subjects to be studied are basic competencies in adaptive subjects, such as: English, Physics, and Mathematics. While on productive subjects, such as: Network Design, Wireless Network, and Computer System. While the object of research are some aspects of mastery of competence learners.

Table 1. Composite models of adaptive subjects and productive subjects

\begin{tabular}{ll}
\hline \multicolumn{1}{c}{ Adaptive Subjects } & \multicolumn{1}{c}{ Productive Subjects } \\
\hline English & Network Design \\
\hline Physics & Wireless Network \\
\hline Mathematics & Computer System \\
\hline
\end{tabular}

The research will be conducted in several public vocational schools in Bantul Regency and limited to Competency of Computer and Network Engineering Expertise. Techniques and instruments used to collect data include: (1) interviews with several teachers related to the research subject, (2) curriculum document studies, especially on basic competencies and learning subject matter; (3) Focus Discussion Group (FDG), (4) learning documents, such as: lesson plan and the subject material of learning to get a picture of the product (model) being piloted, and (5) a questionnaire to measure the successful application of the product in the learning process.

Data analysis technique is a quantitative type obtained from the questionnaire instrument to measure the real condition of the implementation of integrated learning with competency-based learning model (CBT) in an effort to increase the achievement of the competence of learners.

\section{RESULTS AND DISCUSSION Results}

The research that will be carried out is expected to produce the product in the form of a combination of basic competence model on adaptive subjects and productive subjects.

Wibowo, P. A., Kuat, T., \& Sayuti, M. (2018). Integrated learning based on competence in vocational high school. Journal of Vocational Education Studies, 1(2), 71-76. DOI:

https://doi.org/10.12928/joves.v1i2.699. 
The first blend is a combination of basic competencies between the two subjects. By combining the basic competencies will be composed of the subject matter of the combined learning between the two subjects. While to carry out the learning process then proceed with compiling the learning documents such as lesson plan, which is delivered using a competency-based learning model (CBT). In addition to the lesson plan, other documents such as material handouts, worksheets, and evaluation questions were also prepared.

The overall learning process will be measured using an observation sheet of instructional implementation and a questionnaire that will be filled by the learner. Observation sheets include observing the appropriateness of learning implementation to planning, participation of learners in learning and evaluation implementation. While the questionnaire is generally used to ask the level of interest of learners to the implementation of integrated learning with competency-based learning model (CBT).

\section{Discussion}

A discussion of integrated learning topics will be undertaken by several teachers involved with discussing some of the basic competencies in each subject to be integrated. As with the Physics subject of the wave, it will be focused and enriched on radio waves, wave modulation, wave properties, and wave transmission required in the Network Design course. The discussion will be developed until the preparation of instructional materials and preparation of learning scenarios in the lesson plan document.

Next, will be discussed how and who will deliver the integrated learning materials. So in this case, Physics subjects can be delivered by Network Design subject teachers related to the application of waves in wireless network communications or vice versa on the subjects of Network Design will be delivered by Physics subject teachers related to the concepts of the wave or can with collaboration between the two teachers.

In the implementation of learning, observation should be done by teacher collaborators to measure the suitability of planning for its implementation. And that is very important is the level of participation of learners in learning. Ultimately, learning evaluation is expected to be the optimal result of the appointment to measure the level of mastery of the competence of good learners.

After the implementation of learning and evaluation, a review of the implementation of the lesson needs to be undertaken as an attempt to take the necessary corrective actions to form the most appropriate model of integration.

\section{CONCLUSION}

The research to be carried out is expected to produce several things, such as: measuring the level of competence of learners, measuring the extent to which the application of competency-based learning, the realization of an integrated learning model between adaptive subjects and productive subjects.

\section{REFERENCES}

Borg, W. R., \& Gall, M. D. (1983). Educational Research: An Introduction. New York: Longman. Burke, J. W. (1989). Competency Based Education and Training. London: Falmer Press.

Djojonegoro, W. (1996). Lima Puluh Tahun Perkembangan Pendidikan di Indonesia. Jakarta: Department of Education and Culture.

Fogarty, R. (1991). How to Integrate the Curricula. Andover: Skylight Publishing.

MOEC. (2016). Kamus Besar Bahasa Indonesia Edisi Kelima. Jakarta: Bureau of Language Development of Indonesian Ministry of Education and Culture.

Wibowo, P. A., Kuat, T., \& Sayuti, M. (2018). Integrated learning based on competence in vocational high school. Journal of Vocational Education Studies, 1(2), 71-76. DOI:

https://doi.org/10.12928/joves.v1i2.699. 
Rothwell, W. J., Hohne, C. K., \& King, S. B. (2012). Human performance improvement. Abingdon: Routledge.

Setyawan, F., Prahmana, R. C. I., Istiandaru, A., \& Hendroanto, A. (2017). Visualizer's representation in functions. Journal of Physics: Conference Series, 943, 012004. 
Wibowo, P. A., Kuat, T., \& Sayuti, M. (2018). Integrated learning based on competence in vocational high school. Journal of Vocational Education Studies, 1(2), 71-76. DOI: https://doi.org/10.12928/joves.v1i2.699. 